\title{
Faculty Perceptions of Librarians at the University of Manitoba
}

\author{
Gaby Divay, Ada M. Ducas, \\ and Nicole Michaud-Oystryk
}

In early 1985, the faculty at the University of Manitoba were asked to complete a questionnaire exploring their perceptions of the academic librarians on campus. The responses were analyzed according to faculties grouped in five large disciplines and professorial ranks. The analysis of the data focused on faculty-librarian contacts, the usefulness of librarians, the importance of librarians' academic subject background, and their status. Overwhelmingly, librarians were seen as "professionals" with a "service" function. Activities such as research, teaching, and management received low ratings. The results therefore indicate a low acceptance of librarians as full-fledged academic colleagues in the University of Manitoba setting.

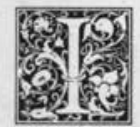

n 1974, librarians at the University of Manitoba (UofM) were included in the newly constituted Faculty Association. In 1980, all fifty-five librarians were ranked according to the traditional requirements of performance, research, service, and where applicable, teaching. The collective agreement, in conjunction with the librarians' promotion guidelines, regulates the advancement of all librarians through the ranks of general, assistant, associate, and librarian. Even though considered academic staff, librarians differ from their faculty colleagues in that they hold continuing appointments rather than tenured positions.

The authors wanted to see how, after eleven years in the faculty bargaining unit and five years in an equivalent rank and promotion system, the academic librarians are regarded by their faculty colleagues, and if they are accepted as useful partners in the academic community.

In the extensive literature on academic status for university librarians, there are very few articles dealing with faculty perception of librarians. The most important one to date is Kathy Cook's "Rank, Status and Contribution of Academic Librarians. ${ }^{\prime \prime}$ It explores the situation at Southern Illinois University-Carbondale (SIU-C), where librarians also hold academic status. John Budd and Patricia Coutant report on the results of a survey closely modeled on Cook's study, examining faculty perceptions of librarians in the somewhat smaller institution of Southeastern Louisiana University (SLU). ${ }^{2}$ Cook invites "a replication of [her] study ... on many campuses" in order to gain a better understanding " of faculty attitudes toward librarians. ${ }^{13}$ As this appeal paralleled our interests, a similar research project was undertaken at the University of Manitoba.

Gaby Divay is German Bibliographer and Cataloger at the University of Manitoba, Ada M. Ducas is Director of Educational Resources and Library Services at the Health Sciences Centre, and Nicole Michaud-Oystryk is Head of Reference Services at the Elisabeth Defoe Library, University of Manitoba, Winnipeg, Manitoba R3T 2 N2. 
$\mathrm{U}$ of $\mathrm{M}$ is one of the largest universities in Canada. It has thirteen libraries with collections totaling 1.4 million volumes and a full-time equivalent staff of about 250 employees, including 55 librarians. The libraries serve a community of approximately 25,000 students, faculty, and citizen borrowers.

\section{METHODOLOGY AND PROFILE}

A questionnaire was designed with the following objectives:

- to determine the extent and nature of faculty-librarian interaction

- to discover the faculty members' perceptions of librarians at the University of Manitoba

In January 1985 the questionnaire was sent to the 1,095 faculty members holding full-time academic appointments. They were coded to facilitate two follow-up mailings to nonrespondents. Faculty members were reassured about the confidentiality of their replies. The final number of usable responses was 633 , or $59 \%$ of the population surveyed. The Statistical Analysis System (SAS) was used to determine the percentages for the analysis of the results.

Faculty were asked to indicate their affiliation with one of twenty faculties/ schools, including an "other" category. Four unlisted units were derived from this last category. Since there were few respondents in some of the faculties/ schools, all the units were regrouped into the following five disciplines for statistical analysis:

- Humanities and social sciences (administrative studies, arts, human ecology, law, social work, St. John's and St. Paul's Colleges)

- Pure and applied sciences (agriculture, engineering, science)

- Health sciences (dental hygiene, dentistry, medical rehabilitation, medicine, nursing, pharmacy)

- Education (education, continuing education, counseling, physical education)

- Fine arts (architecture, art, music)

Thirty-five percent of the respondents were from the humanities and social sciences, $30 \%$ from the pure and applied sciences, $15 \%$ from the health sciences, $12 \%$ from education, and $8 \%$ from the fine arts.
The distribution by rank showed that $38 \%$ of the respondents were professors, $36 \%$ associate professors, $20 \%$ assistant professors, $3 \%$ lecturers, and $3 \%$ instructors.

Twenty percent of respondents used their primary library almost daily, $57 \%$ several times a month, $12 \%$ about once a month, and $10 \%$ several times a year or almost never. Intensive library use, evident for all disciplines, increases with advancement in rank.

\section{ANALYSIS OF RESULTS}

Having studied the profile of the respondents, the authors analyzed the following aspects of the data:

- type of faculty-librarian contact (inside and outside of the library setting)

- perceived usefulness of librarians

- perceived importance of librarians' academic subject background

- perceived status of librarians at the university

Each of these aspects was linked with the grouped disciplines and faculty rank.

\section{CONTACTS}

By far the most common facultylibrarian contact in the library setting was reference assistance ( $90 \%$ ). The next highest was computerized literature searching (51\%). This percentage is noteworthy considering the relatively recent introduction of this service to the libraries. The health sciences and education groups reported the highest degree of contact with 79 and $69 \%$ respectively. This no doubt reflects the early availability of computerized databases in those fields and the subsidization of these services by the respective faculties at the university. In the pure and applied sciences, $52 \%$ indicated contact with regard to computerized literature searching as compared to only $36 \%$ in the humanities and social sciences and $27 \%$ in the fine arts. The higher percentage in the pure and applied sciences might be related to the more extensive and more precise coverage of the subject area in terms of available databases. In the humanities and social sciences, databases became available considerably later, and searching is hampered by the absence of controlled vocabulary due to conceptual difficulties inherent in the subject manner (see table 1). 
TABLE 1

CONTACT IN THE LIBRARY BY FACULTY DISCIPLINE

\begin{tabular}{lccccc}
\hline \hline & $\begin{array}{c}\text { Reference } \\
\text { Assistance } \\
(\%)\end{array}$ & $\begin{array}{c}\text { Collection } \\
\text { Development } \\
(\%)\end{array}$ & $\begin{array}{c}\text { Computerized } \\
\text { Literature } \\
\text { Searching } \\
(\%)\end{array}$ & $\begin{array}{c}\text { Library } \\
\text { Instruction } \\
(\%)\end{array}$ & $\begin{array}{c}\text { Library } \\
\text { Policy } \\
(\%)\end{array}$ \\
\hline Humanities and Social Sciences & 93 & 57 & 36 & 28 & 15 \\
Pure and Applied Sciences & 85 & 34 & 52 & 18 & 15 \\
Health Sciences & 83 & 38 & 79 & 31 & 11 \\
Education & 95 & 44 & 69 & 37 & 21 \\
Fine Arts & 98 & 67 & 27 & 29 & 14 \\
Average & 90 & 47 & 51 & 27 & 15 \\
\hline
\end{tabular}

Faculty-librarian contacts in the area of collection development were more frequent in the humanities and social sciences than in the sciences. This might be attributed to different collection development practices in the various libraries. In some libraries, bibliographers have a higher degree of autonomy than in others where the selection function is to a large extent reduced to purchasing materials requested by the faculty.

Only $27 \%$ reported contact for library instruction with the respondents in the pure and applied sciences claiming the least contact (18\%). Involvement in library policy was low overall (15\%).

The majority of the respondents who commented on other types of interaction specified that they had contact with "librarians" in interlibrary loan, reserve, and circulation, areas not presently staffed by librarians. This indicates that faculty members have difficulty differentiating between professional and nonprofessional staff.

When the responses to the question regarding contacts in the library were related to professorial rank, it does not appear that faculty members in one academic rank are interacting more than those at other levels.

Most contacts outside the library setting occurred in faculty/departmental committees $(51 \%)$ and university social functions (47\%).

For the latter, a sharp contrast was observed in the pure and applied sciences, where roughly half of the $47 \%$ average indicated faculty-librarian interaction. The least interaction took place on search/promotion committees (7\%). The low response could be explained by the fact that librarians and faculty seldom serve on each other's search committees (see table 2).

When these results were linked with professorial rank, the three upper levels consistently reported the highest rate of faculty-librarian contacts. Since active involvement in committees seems almost a prerogative of the higher ranks, librarians should consider their own participation as an excellent opportunity to gain the recognition of their faculty colleagues.

\section{USEFULNESS}

Several questions were posed to determine how faculty perceive the usefulness

TABLE 2

CONTACT OUTSIDE THE LIBRARY BY FACULTY DISCIPLINE

\begin{tabular}{lcccc}
\hline \hline & $\begin{array}{c}\text { Facultyl } \\
\text { Departmental } \\
\text { Committees } \\
(\%)\end{array}$ & $\begin{array}{c}\text { University- } \\
\text { wide } \\
\text { Committees } \\
(\%)\end{array}$ & $\begin{array}{c}\text { Search/ } \\
\text { Promotion } \\
\text { Committees } \\
(\%)\end{array}$ & $\begin{array}{c}\text { University } \\
\text { Social } \\
\text { Functions } \\
(\%)\end{array}$ \\
\hline Humanities and Social Sciences & 38 & 30 & 4 & 52 \\
Pure and Applied Sciences & 55 & 15 & 17 & 24 \\
Health Sciences & 64 & 21 & 5 & 57 \\
Education & 49 & 9 & 2 & 53 \\
Fine Arts & 73 & 22 & 7 & 55 \\
Average & 51 & & 7 & 47 \\
\hline
\end{tabular}


of librarians.

When asked how useful librarians were in keeping faculty members informed of changes in the library, $62 \%$ of the respondents claimed that librarians were useful or very useful. Only $38 \%$ had a favorable opinion about being informed of new publications in their discipline. For these two questions, there were no marked differences between the disciplines. As academic ranking went up, so did the positive perceptions (see table 3 ).

Sixty-four percent of the faculty who rated librarians' assistance in their research found it useful or very useful. Education led with $77 \%$ compared with only $49 \%$ from the pure and applied sciences. When this question was related to rank, the lecturers and the instructors showed that they value this service much more highly than the other functions surveyed.

To the question exploring the usefulness of librarians in assisting faculty in their teaching, $51 \%$ of the respondents indicated that the librarians' assistance was valued. There were no remarkable differences between the ranks, with the exception of the instructors who scored the low- est; their results were only half as positive as those of the other groups.

To recapitulate, assistance in research is the function most appreciated by faculty, followed by information about changes in the library, and assistance in teaching. Information about new publications is far less valued.

To the question "How often do you refer your students to a librarian?," $30 \%$ of the respondents refer students to a librarian almost daily to several times a month, $42 \%$ refer students once a month to several times a year, and the remaining $28 \%$ almost never refer them to a librarian. The responses of the five disciplines showed very different referral patterns among them. The highest ratings came from education and the fine arts. Far behind were the pure and applied sciences and the health sciences. The low referral rate in these disciplines might be related to the nature of scientific research and study, the sciences being less library-dependent than the humanities (see table 4).

When the responses to this question were grouped by faculty rank, no significant differences were observed. The au-

TABLE 3

USEFULNESS BY FACULTY DISCIPLINE

\begin{tabular}{lcccc}
\hline \hline & $\begin{array}{c}\text { Changes } \\
\text { in Library } \\
(\%)\end{array}$ & $\begin{array}{c}\text { Publications } \\
\text { in Discipline } \\
(\%)\end{array}$ & $\begin{array}{c}\text { Assistance } \\
\text { in Research } \\
(\%)\end{array}$ & $\begin{array}{c}\text { Assistance } \\
\text { in Teaching } \\
(\%)\end{array}$ \\
\hline Humanities and Social Sciences & 62 & 36 & 70 & 58 \\
Pure and Applied Sciences & 56 & 38 & 49 & 44 \\
Health Sciences & 62 & 40 & 63 & 42 \\
Education & 66 & 42 & 77 & 56 \\
Fine Arts & 71 & 40 & 60 & 54 \\
Average U+VU* & 62 & 38 & 64 & 51 \\
\hline
\end{tabular}

*Percentages represent sum of responses in useful and very useful categories.

TABLE 4

REFERRAL OF STUDENTS BY FACULTY DISCIPLINE

\begin{tabular}{lccc}
\hline \hline & $\begin{array}{c}\text { Almost Daily } \\
\text { to Several } \\
\text { Times a Month } \\
(\%)\end{array}$ & $\begin{array}{c}\text { Once a Month } \\
\text { to Several } \\
\text { Times a Year } \\
(\%)\end{array}$ & $\begin{array}{c}\text { Almost } \\
\text { Never } \\
(\%)\end{array}$ \\
\hline Humanities and Social Sciences & 34 & 45 & 21 \\
Pure and Applied Sciences & 17 & 44 & 39 \\
Health Sciences & 13 & 51 & 36 \\
Education & 52 & 31 & 17 \\
Fine Arts & 50 & 24 & 26 \\
Average & 30 & 42 & 28 \\
\hline
\end{tabular}


thors recognize that the results to this question could be skewed because some respondents might have answered this question with the library rather than the librarian in mind.

The faculty's perception of the librarians' involvement in the education of their students provided another perspective on the role and usefulness of the librarians in the university setting. While a total of $63 \%$ thought that librarians had some to very substantial involvement in the educational process, $42 \%$ of these respondents felt that librarians had only some involvement. Education valued librarians the highest $(81 \%)$, the pure and applied sciences the lowest (50\%). For many, librarians had no involvement at all in their students' education.

A comparison of the results by discipline with those of faculty at SLU and SIU-C showed noticeable differences. Whereas $58 \%$ of the SLU faculty and $51 \%$ of the SIU-C faculty thought that librarians' contributions were substantial, only a disappointing $21 \%$ of the University of Manitoba faculty believed that librarians had more than some involvement in the education of students.

This lack of recognition is incongruous with the positive response obtained in other areas. It is startling that the value faculty members themselves place on librarians' assistance in their teaching, and the frequency at which they claim to refer students to librarians are not reflected in their view of librarians as contributors to the educational process. How are librarians being rated as useful if it is not for skills that influence the education of students? Why are students being referred to them at a high rate if they are not regarded as special resource people who have a role to play in shaping the future graduates of the university? This contradiction can be explained only by the low expectations faculty have of librarians and/or the misunderstanding of their abilities and responsibilities.

\section{SUBJECT BACKGROUND}

In addition to their degree in library and information science, more and more academic librarians are expected to have or to acquire a subject specialization at the graduate level. Reflecting this trend, many librarians at the University of Manitoba are obtaining additional graduate degrees in subject areas related to their responsibilities. In order to determine how the faculty view the importance of such qualifications, questions relating to the usefulness of a subject background were evaluated.

Overall, a fairly high percentage of the respondents value the subject backgrounds librarians have acquired or are developing. The results indicated that subject specialization was considered most important for collection development, which received an overall rating of $75 \%$, followed by reference assistance with $73 \%$, computerized literature searching and cataloging both with $71 \%$, and library instruction with a comparatively low $57 \%$. It is interesting to note that a specialization is deemed more important by faculty members in those disciplines where librarians have traditionally obtained their education, i.e. the humanities, the social sciences, and education. The sciences do not seem to value a subject background to the same extent. In fact, few librarians working in these fields tend to have a formal science education, but have gained their expertise through experience (see table 5).

When the questions related to the usefulness of a subject specialization were linked with the academic rank of the respondents, the higher ranks generally valued a subject specialization for collection development. These results demonstrate considerable concern for the collection development function. The three highest academic ranks also concurred in their assessment of a subject specialization for cataloging. Like collection development, cataloging is a necessary function in making library materials available. The importance of adequate subject analysis seems to be clearly recognized by the higher ranking academics.

A comparison between faculty members reporting actual contact with librarians and faculty members reporting no contact revealed that the value of a subject specialization was rated considerably higher by 
TABLE 5

VALUE OF SUBJECT BACKGROUND BY FACULTY DISCIPLINE

\begin{tabular}{lccccc}
\hline \hline & $\begin{array}{c}\text { Reference } \\
\text { Assistance } \\
(\%)\end{array}$ & $\begin{array}{c}\text { Computerized } \\
\text { Literature } \\
\text { Searching } \\
(\%)\end{array}$ & $\begin{array}{c}\text { Library } \\
\text { Instruction } \\
(\%)\end{array}$ & $\begin{array}{c}\text { Collection } \\
\text { Development } \\
(\%)\end{array}$ & $\begin{array}{c}\text { Cataloging } \\
(\%)\end{array}$ \\
\hline Humanities and Social Sciences & 80 & 72 & 65 & 85 & 76 \\
Pure and Applied Sciences & 62 & 67 & 46 & 68 & 68 \\
Health Sciences & 55 & 69 & 52 & 54 & 58 \\
Education & 93 & 91 & 63 & 83 & 80 \\
Fine Arts & 75 & 56 & 57 & 76 & 71 \\
Average U+VU* & 73 & 71 & 57 & 75 & 71 \\
Percentagest & $74 / 59$ & $80 / 64$ & $76 / 49$ & $84 / 67$ & \\
\hline
\end{tabular}

"Percentages represent sum of responses in useful and very useful categories.

tPercentages on the left represent responses of faculty who reported contact in those areas. Percentages on the right represent responses of faculty who reported no contact in those areas.

the former group. The ratings improved by at least $15 \%$. The most notable difference was in library instruction, where a $27 \%$ increase was observed. These results strongly suggest that faculty members who have interacted with librarians have a better understanding of their functions and the usefulness of their expertise.

The relatively high value placed on subject specialization for nearly all functions surveyed is particularly interesting. Although this issue of education beyond the library science degree has fueled discussion among librarians for many years, it is clear that faculty recognize the importance of advanced degrees for academic librarians. It is most encouraging for librarians who have obtained or are working toward a graduate or postgraduate degree to see that their advanced qualifications are considered valuable. The faculty's favorable response indicates that librarians should be given support to undertake further studies and to develop their expertise in a specific field. Subject specialization may indeed be a positive step toward a greater acceptance of librarians by faculty as their academic peers.

\section{ROLE AND STATUS}

To determine how faculty perceive the librarians' role within the university community, they were asked to rank four functions in order of importance. As expected in view of traditional labeling, service received the highest ranking, followed by research and teaching, with management being last.
When the question of the librarians' status was raised, the respondents could choose between academics, professionals, nonprofessionals, and other. Overall, $85 \%$ of the respondents viewed librarians as professionals, and only $15 \%$ classed them as academics. The lowest result was recorded from the pure and applied sciences, where only $7 \%$ considered librarians to be academics. In agreement with this poor opinion, $12 \%$ from the pure and applied sciences classified librarians as nonprofessionals, a rating twice as high as the average of $6 \%$ (see table 6).

It was particularly disheartening to compare the results of the status questions with those of SLU and SIU-C. Whereas $41 \%$ of the faculty at SLU and $28 \%$ of the faculty at SIU-C viewed librarians as academics, only $15 \%$ of the faculty did so at the UofM. Conversely, $65 \%$ of the faculty at SIU-C, $57 \%$ at SLU, and a very high $85 \%$ at the UofM saw librarians as professionals. The answers to this question, more than any other, indicate that though the teaching faculty at the UofM acknowledge the value of librarians, they do not consider them their academic peers. It was expected that the perceptions of faculty at the UofM would be as good as or better than those previously reported, but unfortunately, this was not the case.

Linking this question with academic rank revealed that the lecturers' perception of librarians' status was atypical, based on their comparatively high ratings of librarians as academics and nonprofessionals. 
TABLE 6

STATUS BY FACULTY DISCIPLINE

\begin{tabular}{lccc}
\hline \hline & $\begin{array}{c}\text { Academic } \\
(\%)\end{array}$ & $\begin{array}{c}\text { Professional } \\
(\%)\end{array}$ & $\begin{array}{c}\text { Nonprofessional } \\
(\%)\end{array}$ \\
\hline Humanities and Social Sciences & 15 & 88 & 4 \\
Pure and Applied Sciences & 7 & 81 & 12 \\
Health Sciences & 23 & 84 & 4 \\
Education & 18 & 90 & 3 \\
Fine Arts & 12 & 82 & 6 \\
Average $^{*}$ & 15 & 85 & 6 \\
\hline
\end{tabular}

-Because multiple answers were accepted, the total result exceeds $100 \%$.

Only nineteen respondents chose the "other" category, but their observations were quite revealing. Some felt that "librarian" should have been included in the options, considering that title expressive enough. While one termed librarians as researchers, other opinions were less favorable. Semiprofessionals, support staff, and trained service personnel figured among the suggestions. Certain remarks indicated that the respondents had no idea of a librarian's functions, an impression well confirmed in the invited comments.

\section{COMMENTS}

Almost one quarter of the respondents welcomed the opportunity to express themselves freely about the questionnaire, the issues raised in it, or other areas of concern. While $59 \%$ of these directed their comments to the library services and collections, $41 \%$ chose to voice their opinions more specifically about librarians. It was remarkable that many respondents seem to consider the library simply as an institution, with little regard for the people who are instrumental in its functioning.

Several respondents recognized their lack of knowledge or experience to which they attributed some of their negative responses. It was noted that many faculty members make no distinction between librarians and other library staff. Although a statement at the beginning of the questionnaire attempted to define the librarians and their function, it was clear that misconceptions about the role of the different staff components remain common even in the academic community.

Some respondents questioned the high number of librarians employed by the university and objected to their salaries. These comments echoed the numerous complaints concerning the lack of funds to develop the collections. Benefits such as research/study leaves were criticized not only for financial reasons, but also on philosophical grounds. The importance of advanced degrees was also reduced to a monetary level. Some felt that it was illadvised to spend money to employ librarians with higher degrees when librarians were destined to service and the collections were inadequate. There appears to be little recognition of the fact that collections, no matter how large, lose their value if they are not properly organized or fully exploited.

While some supported subject specialization in certain areas like law or music, others thought that it was unrealistic to expect librarians to be educated in the diverse fields of study offered at the university. Subject specialization was judged particularly valuable for collection development. However, some expressed little respect for librarians' competence in this area, and others even suggested a more active involvement of faculty in collection development.

The research role of librarians is not regarded highly by all. One respondent saw it as a possibility only if the institution offered a degree in library science. It was not clear if he or she meant that all academic librarians could then pursue research interests or that only faculty members affiliated with such a school should have that responsibility. Certainly, this would preclude all research in subject areas other than library science.

In summary, the faculty members' per- 
ceptions of librarians were colored by their lack of knowledge. Many declared openly that they did not know enough about librarians' educational background and training. The librarian's role in an academic institution was often questioned or misunderstood. Respondents noted the need for more contact between faculty and librarians. A higher profile and increased academic involvement seem implicit in this demand, as is a better understanding of the librarian's role. A closer association between the two groups was deemed desirable to fulfill the educational and research functions of the university.

\section{CONCLUSION}

The survey revealed that faculty at the University of Manitoba perceive librarians mainly in terms of their service role. The results confirmed a relatively high rate of interaction between faculty and librarians, a positive outlook on the usefulness of librarians, and the value of their present and future subject expertise. It is therefore disconcerting that in spite of these findings, librarians are not commonly viewed as contributing greatly to the overall educational process. The support function is further emphasized by the general opinion that University of Manitoba librarians are professionals rather than academics. This seems to imply that faculty members do not recognize the academic role that librarians are contractually obliged to fulfill. In particular, the pure and applied sciences consistently gave evidence of their poor opinion of librarians.

As many of the comments and hesitations in the answers to the "usefulness" and "subject background" questions indicate, faculty in all disciplines are often not aware of what the librarians actually do and what specific benefits could be derived from the various services offered. There exists widespread confusion as to who among the library personnel are actually the professionally trained and educated colleagues. This reflects the blurred picture offered by a large academic library, where many important functions are performed by nonprofessional personnel. With increasing budget restraints, this problem is not likely to disappear. In many ways, it is not surprising that the supervisory employee behind the circulation desk or in charge of interlibrary loan should impress both faculty and students as being a librarian. It seems that anyone "in charge" of a particular area emanates this impression more readily than someone who fulfills less noticeable activities such as collection development or cataloging. These tasks involve commendable but not as easily recognized abilities for the acquisition, organization, or retrieval of library materials. The difference between the professional and the nonprofessional often lies precisely in a wider scope of knowledge and a sounder understanding of the library's goals. As long as the faculty are themselves ill-informed about the latter, they cannot be expected to appreciate the librarians' contribution as fully as would be desirable.

To correct these misconceptions, efforts should be made to inform the faculty more adequately of the librarian's potential. Faculty should be made aware that librarians will respond to their immediate information needs, but also have a responsibility to fulfill the long-term goals of the institution. More awareness would promote a deeper understanding of what faculty and librarians can achieve together in their efforts to provide high-quality education at the undergraduate and graduate levels. Increased interaction through consultation, committees, and workshops might well result in a different perception of the librarian's research, teaching, and management responsibilities.

Faculty might come to recognize that the librarian's research is not a futile activity, but rather a legitimate contribution to an academic field of knowledge. Furthermore, the research process allows firsthand experience of library services, and thus may lead to valuable suggestions as to how to improve them.

Library instruction most closely parallels the teaching component of faculty duties. One could therefore expect that bibliographic instruction would be recognized by faculty as kindred to their activities. However, few are aware of this function, or view it as an area where librarians demonstrate their special information 
skills. In order to develop it further, librarians should lobby to teach bibliography courses presently on the curriculum. This would result in a closer working relationship with faculty and might increase the acceptance of librarians as academics.

Since research and teaching are not widely accepted by faculty as academic responsibilities of librarians, it is surprising to see that the management role, which is related to librarians' professionalism, is even less acknowledged. Many librarians have administrative responsibilities, and with the general trend toward automation, management is likely to become increasingly more important. While re- search and teaching foster dialogue with faculty, management is less conducive to such interaction. Therefore, librarians must strive to impress through their effectiveness in this area.

The study clearly demonstrates that the functions of research, teaching, and management play a negligible role in the University of Manitoba faculty's perceptions of librarians. While the service function will always remain important, librarians must take an active role in promoting their image through sound research, formal teaching, and effective management. This will improve the librarians' chances to become fully accepted by their faculty peers.

\section{REFERENCES}

1. M. Kathy Cook, "Rank, Status and Contribution of Academic Librarians as Perceived by Teaching Faculty at Southern Illinois University, Carbondale," College \& Research Libraries 42:214-23 (May 1981).

2. John Budd and Patricia Coutant, Faculty Perceptions of Librarians: A Survey (Betheseda, Md.: ERIC Document Reproduction Service, ED 215 697, 1981).

3. Cook, "Rank, Status and Contribution," p.221. 